Vol. 9, No. 1, pp. 1-19, April 2021

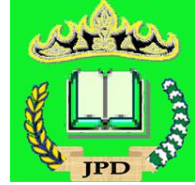

PEDAGOGI: JURNAL PENDIDIKAN DASAR

http://jurnal.fkip.unila.ac.id/index.php/pgsd

\title{
Hubungan Peran Orang Tua dalam Pendampingan dan Motivasi Belajar dengan Hasil Belajar Anak di Era New Normal Pandemi Covid-19
}

\author{
Ni Nyoman Ervalna $1^{1}$, Rapani $2^{2}$, Amrina Izzatika $3^{3}$ \\ ${ }^{1}$ FKIP, Universitas Lampung \\ ${ }^{2}$ FKIP, Universitas Lampung \\ ${ }^{3}$ FKIP, Universitas Lampung
}

Email:nyomanervalna@gmail.com

\begin{abstract}
The problem in this research is the low learning outcomes of low grade students at SD Negeri 1 Rama Murti. This study aims to determine the significant relationship between the role of parents in mentoring and learning outcomes, the role of parents in learning motivation and learning outcomes, the role of parents in mentoring and learning motivation, and the role of parents in mentoring and learning motivation together with learning outcomes of low grade SD Negeri 1 Rama Murti. This type of research is ex-postfacto correlation. The data collection techniquesused werw questionnaires and documentation study. The instrument for data collection is a questionnarie with a linkert scale, wich was previously tested for validity and reliability. Data analysis using product moment correlation multiple correlation. The result showed that there was a significant relationship between the role of parents in mentoring and learning motivation together with learning outcomes with a correlation coefficient value of 0,687 being at a level of "Strong".
\end{abstract}

Keywords: learning outcomes, mentoring, motivation.

Abstrak: Masalah dalam penelitian ini adalah rendahnya hasil belajar peserta didik kelas rendah SD Negeri 1 Rama Murti. Penelitian ini bertujuan untuk mengetahui hubungan signifikan antara peran orang tua dalam pendampingan dengan hasil belajar, peran orang tua dalam motivasi belajar dengan hasil belajar, peran orang tua dalam pendampingan dan motivasi belajar, dan peran orang tua dalam pendampingan dan motivasi belajar secara bersama-sama dengan hasil belajar anak kelas rendah SD Negeri 1 Rama Murti. Jenis penelitian yaitu ex-postfacto kolerasi. Teknik pengumpulan data yang dilakukan yaitu angket (kuisioner) dan studi dokumentasi. Instrumen pengumpulan data berupa angket skala linkert, yang sebelumnya diuji validitas dan reliabilitas. Analisis data menggunakan kolerasi product moment dan multiple correlation. Hasil penelitian menunjukan terdapat hubungan yang signifikan antara peran orang tua dalam pendampingan dan motivasi belajar secara bersama-sama dengan hasil belajar dengan nilai koefisien kolerasi sebesar 0,687 pada taraf "Kuat".

Kata Kunci: hasil belajar, pendampingan, motivasi. 


\section{PENDAHULUAN}

Di Indonesia pandemi Covid-19 hingga saat ini belum juga berakhir. Virus ini pertama kali muncul dari kota Wuhan, Cina sejak Desember 2019. Pada 30 Januari 2020, WHO memberikan pengumuman yang mengejutkan mengenai pandemi covid-19 (corona virus diseases) ke seluruh dunia. Di Indonesia sendiri, penyebaran virus ini ditemukan pertama kali pada tanggal 2 maret 2020, dan hal ini disampaikan langsung oleh Presiden Joko Widodo. Berdasarkan data dari covid19.go.id terdapat 23,165 orang terinfeksi dengan jumlah kematian 1,418 jiwa, dan jumlah pasien yang sembuh 5,877 orang.

Pemerintah Indonesia telah melakukan berbagai upaya untuk memutus rantai penyebaran virus corona, diantaranya ialah mengeluarkan PP Nomor 21 tahun 2020 tentang Pembatasan Sosial Berskala Besar Dalam Rangka Percepatan Penanganan Covid-19 yang berakibat pada pembatasan berbagai aktivitas diantaranya pembatasan berbagai aktivitas di sekolah. Sementara itu aktivitas Belajar Dari Rumah (BDR) secara resmi di keluarkan melalui Surat Edaran Mendikbud Nomor 36962/MPK.A/HK/2020 tentang pembelajaran secara daring dan bekerja dari rumah dalam rangka pencegahan penyebaran Corona Virus Disease (COVID- 19.

Kemudian pada tanggal 13 Juli 2020 pemerintah memutuskan jadwal masuk sekolah tahun ajaran baru 2020/2021 sebagai awal dimulainya era new normal dalam dunia pendidikan. New normal adalah kebijakan membuka kembali aktivitas dan kegiatan publik secara terbatas dengan menggunakan standar kesehatan yang sebelumnya tidak ada, sebelum pandemi. New normal merupakan 
tahapan baru setelah kebijakan pembatasan sosial yang diberlakukan untuk mencegah penyebaran wabah virus Covid 19.

Memasuki era new normal ini pemerintah memberikan himbauan kepada seluruh masyarakat agar menetapkan protokol kesehatan yang dianjurkan dan menaati aturan yang dibuat. Dunia pendidikan pun terpaksa tetap diliburkan dan diganti dengan sistem pembelajaran daring (dalam jaringan) yang berbasis digital.Metode pembelajaran daring secara penuh sudah menjadi pilihan di tengah situasi new normal (tatanan kehidupan baru) saat ini. Metode pembelajaran secara daring ini memang bukan hal baru bagi masyarakat Indonesia. Di era new normal ini membuat kita harus bisa menyesuaikan metode pembelajaran yang sesuai dengan kondisi saat ini dimana pembelajaran daring menjadi salah satu solusinya.

Pembelajaran daring ditujukan kepada seluruh satuan pendidikan mulai dari TK hingga perguruan tinggi. Dipilihnya cara ini dikarenakan berkembangnya revolusi industri 4.0. Berkembangnya revolusi industri sangat mendukung terlaksananya pembelajaran daring, karena pembelajaran daring adalah pembelajaran berbasis digital dengan jaringan internet yang mampu menunjang pembelajaran untuk dilakukan tanpa adanya interaksi fisik antara pendidik dan peserta didik. Sehingga kecanggihan teknologi jaman sekarang diharapkan mampu menunjang kegiatan pembelajaran daring tersebut. Namun pada jenjang pendidikan TK dan $\mathrm{SD}$, pembelajaran daring memerlukan keterlibatan orang tua langsung dalam pelaksanaannya. 
Pemindahan proses pembelajaran dari sekolah ke rumah, mau tak mau peran orang tua menjadi lebih sentral, karena selain mengasuh anak kini orang tua menggantikan peran utama seorang guru dalam mendampingi anak belajar di rumah. Artinya orang tua menjadi garda terdepan dalam mendampingi anak pada proses belajar selama pandemi. Didukung oleh pendapat Nurlaeni dalam Euis (2017: 242) Orang tua pada awalnya berperan dalam membimbing sikap serta keterampilan yang mendasar, seperti pendidikan agama untuk patuh terhadap aturan, dan untuk pembiasaan yang baik, namun perannya menjadi meluas yaitu sebagai pendamping pendidikan akademik. Sedangkan Prabhawani (2016: 775) menekankan bahwa pelaksanaan pendidikan merupakan tanggung jawab orang tua dan masyarakat sekitar, tidak hanya tanggung jawab lembaga pendidikan saja.

Dengan dilaksanakannya pembelajaran dari rumah, anak akan kekurangan ruang untuk berinteraksi sehingga tak dapat bersosialiasi. Selain itu, dari segi psikologi mempengaruhi semangat belajar anak, mereka merasa cepat bosan kerena kurangnya motivasi belajar pada anak yang kemudian akan mempengaruhi hasil belajarnya. Oleh sebab itu anak-anak harus mendapatkan motivasi atau dorongan dari orang-orang terdekatntya terutama orang tua. Sejalan dengan hal tersebut Rakhmawati (2015: 242) mengungkapkan bahwa pengasuhan anak merupakan suatu kegiatan berkelanjutan melalui proses interaksi orang tua dan anak untuk mendorong pertumbuhan serta perkembangan anak yang optimal. Paparan di atas menunjukkan bahwa proses interaksi antara orang tua dengan anak adalah suatu bentuk dorongan orang tua untuk anak, agar mereka lebih termotivasi sehingga 
pertumbuhan dan perkembangan akademik anak menjadi lebih optimal yang kemudian berpotensi pada meningkatnya hasil belajar anak.

Pada kenyataannya permasalahan yang ditemui di SD Negeri 1 Rama Murti diketahui bahwa hasil belajar peserta didik pada kelas rendah masih dibawah ratarata terutama pada mata pelajaran matematika, kemungkinan hal tersebut disebabkan oleh kurangnya perhatian orang tua dalam belajar, kurangnya memperhatikan disiplin belajar anak, kurangnya orang tua dalam memotivasi belajar.

Faktor yang mempengaruhi kurangnya peran orang tua dalam pendampingan belajar pada anak diantaranya ialah kesulitan orang tua dalam menumbuhkan minat belajar anak, tingkat pendidikan orang tua yang berbeda-beda, sehingga tidak semua orang tua dapat memahami materi pembelajaran, kemudian keterbatasan orang tua dalam mengoprasikan gadget membuat orang tua sulit mendampingi anak dalam pembelajaran daring. Selain dari ketiga faktor tersebut pekerjaan orang tua juga menjadi salah satu faktor yang sangat mempengaruhi orang tua dalam pendampingan pada anak, karena suatu kewajiban yang mengharuskan orang tua untuk bekerja.

Seperti yang kita ketahui bahwa orang tua memiliki kewajiban untuk menafkahi dan memenuhi kebutuhan keluarganya. Jadi tiap orang tua memiliki waktu yang berbeda-beda dalam meluangkan waktu mereka apalagi jika orang tua sama-sama sibuk bekerja sehingga tidak setiap saat bisa menemani anak-anaknya belajar. Mayoritas pekerjaan orang tua di SD Negeri 1 Rama Murti adalah sebagai petani 
dan buruh. Mereka bekerja dari pagi hingga menjelang siang, kemudian pada sore hari mereka kembali ke sawah untuk mencari rumput untuk makanan ternak, hal ini mengakibatkan banyak orang tua yang kelelahan. Kesibukan orang tua dalam bekerja tersebut menyebabkan kurangnya kesadaran orang tua mengenai perannya dalam pendampingan belajar anak sehingga berpengaruh terhadap hasil belajar anak. Berikut data pekerjaan orang tua pada peserta didik kelas rendah di SD Negeri 1 Rama Murti

Tabel 1. Pekerjaan Orang Tua SD Negeri 1 Rama Murti

\begin{tabular}{|c|c|c|c|c|c|c|}
\hline \multirow[t]{2}{*}{ No } & \multirow[t]{2}{*}{$\begin{array}{c}\text { Pekerjaan Orang } \\
\text { Tua }\end{array}$} & \multirow{2}{*}{$\begin{array}{c}\text { Jumlah } \\
\text { Peserta } \\
\text { Didik }\end{array}$} & \multicolumn{2}{|c|}{$\begin{array}{c}\text { Jumlah Orang } \\
\text { Tua }\end{array}$} & \multicolumn{2}{|c|}{ Presentase (\%) } \\
\hline & & & Ayah & Ibu & Ayah & Ibu \\
\hline $\begin{array}{l}1 . \\
2 . \\
3 . \\
4 .\end{array}$ & $\begin{array}{l}\text { Petani } \\
\text { Buruh } \\
\text { Wiraswasta } \\
\text { PNS }\end{array}$ & 43 & $\begin{array}{c}24 \\
13 \\
4 \\
2\end{array}$ & $\begin{array}{c}16 \\
10 \\
5 \\
2\end{array}$ & $\begin{array}{c}55,92 \\
30,42 \\
7,95 \\
5,71\end{array}$ & $\begin{array}{c}40,95 \\
20,55 \\
13,24 \\
5,71\end{array}$ \\
\hline & Jumlah & & 43 & 33 & 100 & 78,45 \\
\hline
\end{tabular}

Sumber: Dokumen Kelas Rendah SD Negeri 1 Rama Murti

Berdasarkan tabel di atas mengenai data pekerjaan orang tua pada peserta didik SD Negeri 1 Rama Murti diperoleh data dari 43 orang tua peserta didik dengan jumlah ayah dan ibu paling banyak yang bekerja sebagai petani dengan jumlah 40 orang $(96,87 \%)$, buruh 23 orang $(50,97 \%)$, wiraswasta 9 orang $(21,19 \%)$, PNS 4 orang $(11,42 \%)$ dan sisanya $10(20,55 \%)$ orang bekerja sebagai ibu rumah tangga.

Untuk membuktikan hasil belajar peserta didik rendah peneliti melakukan wawancara langsung terhadap guru kelas I, II, dan III. Kemudian peneliti meminta data hasil ujian tengah semester ganjil pada mata pelajaran matematika. Berikut 
nilai ujian tengah semester ganjil pada peserta didik kelas I, II, dan III di SD Negeri 1 Rama Murti.

Tabel 2. Nilai Ujian Tengah Semester Ganjil SD Negeri 1 Rama Murti

\begin{tabular}{|c|c|c|c|c|c|}
\hline No. & $\begin{array}{c}\text { Peserta } \\
\text { Didik }\end{array}$ & KKM & Ketuntasan & $\begin{array}{c}\text { Presentase } \\
(\boldsymbol{\%})\end{array}$ & Keterangan \\
\hline 1. & 43 & 70 & 12 & 26,78 & Tuntas \\
& & & 31 & 73,22 & $\begin{array}{c}\text { Belum } \\
\text { Tuntas }\end{array}$ \\
\cline { 3 - 6 } & & & & & \\
\hline
\end{tabular}

Sumber: Dokumen Kelas Rendah SD Negeri 1 Rama Murti

Berdasarkan tabel di atas diketahui bahwa nilai ujian tengah semester ganjil khususnya pada mata pelajaran matematika di SD Negeri 1 Rama Murti, dibawah standar Kriteria Ketuntasan Minimum. Adapun KKM yang telah ditetapkan yaitu 70 .

Dari tabel di atas diketahui bahwa 31 peserta didik memperoleh nilai dibawah KKM, sedangkan peserta didik dengan nilai telah mencapai KKM sebanyak 12 peserta didik. Jadi dapat disimpulkan bahwa hasil belajar peserta didik kelas rendah SD Negeri 1 Rama Murti masih di bawah standar KKM.

Nampaknya hasil belajar yang menurun tidak hanya dipengaruhi oleh peran pendampingan orang tua saja namun kegiatan belajar dari rumah (BDR) yang dilakukan anak-anak selama pandemi berlangsung memunculkan beragam kondisi diantaranya adalah jenuh dan menurunnya semangat anak-anak dalam belajar. Dalam hal ini peran orang tua tidak cukup hanya dengan mendamping saja tetapi orang tua juga perlu memberikan motivasi kepada anak, 
agar anak tetap bersemangat dalam melakukan kegiatan di rumah. Seperti yang dikatakan oleh Yuliyanti (2014: 257) bahwa pada dasarnya anak memiliki motivasi untuk melakukan suatu hal, apabila ia mendapatkan sebuah dorongan dari orang-orang terdekat seperti orang tua. Dikuatkan derngan pendapat Harahap (2018: 25) mengemukakan bahwa motivasi adalah serangkaian usaha dalam menciptakan kondisi tertentu untuk memberi rangsangan agar seseorang ingin melakukan sesuatu.

Peran-peran ini dimunculkan oleh orang tua, sebagai salah satu cara pengasuhan orang tua terhadap anaknya. Diantara peran orang tua dalam memotivasi belajar anak yaitu pemberian perhatian, pemberian hadiah, pemberian pujian, pemberian hukuman. Hal tersebut dianggap perlu untuk membantu menumbuhkan semangat belajar anak, sehingga hasil belajar anak dapat meningkat.

Dari hasil pengamatan tersebut maka peneliti merasa perlu melakukan penelitian di SD Negeri 1 Rama Murti karena faktor kurangnya peran orang tua dalam pendampingan dan pemberian motivasi terhadap anak sehingga berpengaruh terhadap hasil belajarnya. Maka peneliti mengangkat judul Hubungan Peran Orang Tua dalam Pendampingan dan Memotivasi dengan Hasil Belajar Anak di Era New Normal Pandemi Covid-19.

\section{METODE}

Penelitian ini menggunakan penelitian expost facto kolerasi. Penelitian expostfacto adalah suatu penelitian yang dilakukan untuk meneliti peristiwa yang telah terjadi dan kemudian melihat kebelakang untuk mengetahui faktor-faktor 
yang dapat menimbulkan kejadian tersebut penelitian ini dilakukan untuk mengetahui kuat dan lemahnya hubungan antara peran orang tua dalam pendampingan dengan hasil belajar, hubungan peran orang tua dalam motivasi belajar dengan hasil belajar, dan hubungan peran orang tua dalam pendampingan dan motivasi belajar secara bersama-sama dengan hasil belajar anak.

Penelitian ini dilaksanakan pada semester ganjil tahun ajaran 2020/2021 di kelas I, II, dan III SD Negeri 1 Rama Murti Kecamatan Seputih Raman Kabupaten Lampung Tengah.

Pada penelitian ini populasi adalah orang tua peserta didik kelas I, II, dan III SD Negeri 1 Rama Murti yang berjumlah 43 orang tua peserta didik. Dalam penelitian ini peneliti menentukan sempel pada penelitian ini menggunakan teknik sempling jenuh yang merupakan kategori dari teknik sempling non probability sampling. Sempling jenuh adalah teknik penentuan sempel bila semua anggota populasi digunakan sebagai sempel. Alasan peneliti menggunakan sempel jenuh adalah karena populasi dalam penelitian ini $<100$ orang. Jadi berdasarkan data populasi yang ada sempel yang peneliti ambil adalah seluruh orang tua baik ayah maupun ibu dari peserta didik kelas I, II, III SD Negeri 1 Rama Murti dengan jumlah 43 orang tua peserta didik.

Teknik pengumpulan data yang digunakan pada penelitian ini berupa angket dan dokumentasi . Variabel dalam penelitian ini yaitu variabel bebas adalah peran orang tua dalam pendampingan $\left(\mathrm{X}_{1}\right)$ dan peran orang tua dalam motivasi belajar $\left(\mathrm{X}_{2}\right)$, sedangkan variabel terikat adalah hasil belajar anak $(\mathrm{Y})$. 
Teknik analisis data untuk mengetahui hubungan variabel $\mathrm{X}$ dengan variabel Y yang artinya hubungan yang terjadi dapat berlaku untuk populasi (dapat digeneralisasikan) yaitu menggunakan rumus uji korelasi product moment dengan kriteria pengujian jika $t_{\text {hitung }}>t_{\text {tabel }}$ maka $H_{o}$ ditolak dan $\mathrm{H}_{\mathrm{a}}$ diterima dan jika $t_{\text {hitung }}<$ $\mathrm{t}_{\text {tabel }}$ maka $\mathrm{H}_{\mathrm{o}}$ diterima dan $\mathrm{H}_{\mathrm{a}}$ ditolak dengan mengambil taraf signifikansi 5\%.

\section{HASIL DAN PEMBAHASAN}

Pengumpulan data dilaksanakan di SD Negeri 1 Rama Murti pada hari Senin, 24 Mei 2021 di kelas I, II, dan III. Penelitian dilaksanakan dengan menyebarkan angket peran orang tua dalam pendampingan dan motivasi belajar kepada responden yaitu orang tua dari peserta didik kelas rendah SD Negeri 1 Rama Murti sebanyak 43 orang.

Data yang diambil dalam penelitian ini berupa instrumen angket tentang peran orang tua dalam pendampingan dan motivasi belajar. Pengambilan data dilakukan sebanyak 2 kali pertemuan. Sedangkan untuk data hasil belajar, peneliti menggunakan nilai ulangan tengah semester peserta didik kelas I, II, dan III SD Negeri 1 Rama Murti. Data tersebut didapatkan dari dokumentasi pendidik kelas I, II, dan III saat peneliti melaksanakan penelitian pendahuluan pada tanggal 12 Mei 2021.

Berdasarkan hasil uji normalitas variabel peran orang tua dalam pendampingan (X1) didapat hasil sebesar 3,521, variabel peran orang tua dalam motivasi belajar (X2) didapat hasil sebesar 2,562 dan variabel hasil belajar (Y) 
didapat hasil sebesar 8,688. Dengan demikian dapat disimpulkan bahwa sebaran data dari ketiga variabel tersebut terdistribusi normal.

Berdasarkan hasil uji linearitas diperoleh hasil $\mathrm{X}_{1}$ dengan $\mathrm{Y}$ didapati bahwa $\mathrm{F}_{\text {hitung }}=23,74>\mathrm{F}_{\text {tabel }}=4,05$ hal ini berarti Ho ditolak maka ada hubungan liner. Pada perhitungan uji liniearitas $X_{2}$ dengan $Y$ didapati bahwa $F_{\text {hitung }}=28,11>F_{\text {tabel }}$ $=4,05$ ini berarti data juga berpola linier.

Berdasarkan hasil perhitungan uji hipotesis pertama dalam penelitian ini diperoleh hasil koefisien kolerasi antara $\mathrm{X}_{1}$ dan $\mathrm{Y}$ sebesar 0,605 dengan kriteria kuat, dilihat pada kriteria interpretasi koefisien kolerasi. Kontribusi variabel $\mathrm{X}_{1}$ terhadap variabel Y sebesar 36,66\%. Hal ini berarti hipotesis diterima, terdapat hubungan yang signifikan antara peran orang tua dalam pendampingan dengan hasil belajar anak di era new normal pandemi covid-19.

Hasil perhitungan uji hipotesis kedua dalam penelitian ini diperoleh hasil koefisien kolerasi antara $\mathrm{X}_{2}$ dan $\mathrm{Y}$ sebesar 0,636 dengan kriteria kuat, dilihat pada kriteria interpretasi koefisien kolerasi. Kontribusi variabel $\mathrm{X}_{2}$ terhadap variabel $\mathrm{Y}$ sebesar 40,45\%. Hal ini berarti hipotesis diterima, terdapat hubungan yang signifikan antara peran orang tua dalam motivasi belajar dengan hasil belajar anak di era new normal pandemi covid-19.

Hasil perhitungan uji hipotesis ketiga dalam penelitian ini diperoleh hasil koefisien kolerasi antara $X_{1}$ dan $X_{2}$ sebesar 0,634 dengan kriteria kuat, dilihat pada kriteria interpretasi koefisien kolerasi. Kontribusi variabel $\mathrm{X}_{1}$ terhadap variabel $\mathrm{X}_{2}$ sebesar 40,20\%. Hal ini berarti hipotesis diterima, terdapat hubungan 
yang signifikan antara peran orang tua dalam pendampingan dengan peran orang tua dalam motivasi belajar di era new normal pandemi covid-19.

Kemudian untuk hipotesis keempat menentukan $\mathrm{F}_{\text {tabel }} \mathrm{dk}$ pembilang $=\mathrm{k}=2$ dan dk penyebut $=(n-k-1)=(43-2-1)=40$ dengan $\alpha 0,05$ maka, diperoleh $\mathrm{F}_{\text {tabel }}=4,05$. Interpretasi $\mathrm{F}_{\text {hitung }}=17,87>\mathrm{F}_{\text {tabel }}=4,05$ berarti signifikan. Hal ini berarti hipotesis diterima, terdapat hubungan yang signifikan antara peran orang tua dalam pendampingan dan motivasi belajar secara bersama-sama dengan hasil belajar anak di era new normal pandemi covid-19. Kontribusi $\mathrm{X}_{1}, \mathrm{X}_{2}$, terhadap $\mathrm{Y}$ sebesar 47,20\% sedangkan, 52,8\% dipengaruhi oleh faktor lain di luar penelitian seperti; peran sekolah, masyarakat, kecerdasan intelektual, bakat, minat, keterampilan mengajar guru maupun cara belajar peserta didik itu sendiri, dan lain sebagainya.

Berdasarkan hasil perhitungan uji hipotesis, dapat diketahui bahwa terdapat hubungan yang signifikan antara peran orang tua dalam pendampingan dengan hasil belajar anak, dengan koefisien kolerasi antara variabel $\mathrm{X}_{1}$ dan variabel $\mathrm{Y}$ sebesar 0,605 itu berarti kolerasi tersebut bertanda positif dengan kriteria kuat. Selanjutnya kontribusi variabel $\mathrm{X}_{1}$ terhadap variabel $\mathrm{Y}$ sebesar $36,66 \%$. Hal itu berarti peran orang tua dalam pendampingan memiliki hubungan sebesar 36,66\% terhadap hasil belajar anak. Terdapat hubungan yang signifikan antara peran orang tua dalam pendampingan dengan hasil belajar anak.

Peran orang tua dalam pendampingan merupakan faktor yang sangat berpengaruh terhadap pencapaian hasil belajar anak. Apabila peran orang tua selalu peduli terhadap pendidikan anak, umumnya pengaruhnya positif terhadap 
perkembangan dan hasil belajar anak. Dwi (2018: 9) bahwa pendampingan orang tua dalam proses belajar anak adalah upaya orang tua untuk menemani, memberikan bantuan dalam mengatasi masalah anak dalam belajar, memberikan dorongan, motivasi, dukungan, pengawasan dan memberikan fasilitas pada anak agar semangat dalam belajar. Keterlibatan orang tua terhadap pendidikan anak di rumah belum cukup apabila sekolah memiliki program yang baik dan keluarga ikut membantu maka hasil belajar anak akan meningkat.

Terdapat hubungan yang signifikan antara peran orang tua dalam motivasi belajar dengan hasil belajar anak. Berdasarkan perhitungan diperoleh koefisien kolerasi antara variabel $\mathrm{X} 2$ dan variabel $\mathrm{Y}$ sebesar 0,636 itu berarti kolerasi tersebut bertanda positif dengan kriteria kuat. Selanjutnya kontribusi variabel X2 terhadap variabel $\mathrm{Y}$ sebesar 40,45\%. Hal itu berarti peran orang tua dalam motivasi belajar memiliki hubungan sebesar $40,45 \%$ terhadap hasil belajar anak. Terdapat hubungan yang signifikan antara peran orang tua dalam motivasi belajar dengan hasil belajar anak.

Motivasi belajar dari orang tua untuk anaknya tentu sangat diperlukan dan dibutuhkan, agar tujuan pembelajaran yang diinginkan dapat tercapai dengan maksimal serta hasil belajar yang baik dapat tercapai. Jika orang tua tidak memberikan motivasi untuk anaknya, maka akan berpengaruh pada hasil belajar anak. Menurut Uno (2011: 9) motivasi adalah suatu dorongan yang timbul oleh adanya rangsangan-rangsangan dari dalam maupun dari luar sehingga seseorang berkeinginan untuk mengadakan perubahan tingkah laku atau aktivitas tertentu yang lebih baik dari sebelumnya. 
Terdapat hubungan yang signifikan antara peran orang tua dalam pendampingan dan peran orang tua dalam motivasi belajar. Berdasarkan perhituangan diperoleh koefisien kolerasi antara variabel $X_{1}$ dan variabel $X_{2}$ sebesar 0,634 itu berarti kolerasi tersebut bertanda positif dengan kuat. Selanjutnya kontribusi variabel $X_{1}$ terhadap $X_{2}$ sebesar $40,20 \%$. Hal itu berarti peran orang tua dalam pendampingan memiliki hubungan sebesar $40,20 \%$ dengan peran orang tua dalam motivasi belajar. Terdapat hubungan positif dan signifikan antara peran orang tua dalam pendampingan dengan peran orang tua dalam motivasi belajar.

Seperti yang dikemukakan oleh Dwi (2018: 9) bahwa pendampingan orang tua dalam proses belajar anak adalah upaya orang tua untuk menemani, memberikan bantuan dalam mengatasi masalah anak dalam belajar, memberikan dorongan, motivasi, dukungan, pengawasan dan memberikan fasilitas pada anak agar semangat dalam belajar seperti yang disebutkan dalam penelitian Nurkholis dalam Euis (2020: 257) bahwa dampak dari situasi pandemi Covid-19 pada peserta didik adalah kejenuhan dan kebosanan. Dalam hal ini peran orang tua tidak cukup hanya dengan mendamping saja tetapi orang tua juga perlu memberikan motivasi kepada anak, agar anak tetap bersemangat dalam melakukan kegiatan di rumah. Seperti yang dikatakan oleh Yuliyanti dalam Euis (2014: 257) bahwa pada dasarnya anak memiliki motivasi untuk melakukan suatu hal, apabila ia mendapatkan sebuah dorongan dari orang-orang terdekat seperti orang tua 
Serta terdapat hubungan yang signifikan antara peran orang tua dalam pendampingan dan motivasi belajar secara bersama-sama dengan hasil belajar anak. Berdasarkan hasil yang diperoleh dalam uji signifikansi atau uji-F yang telah dilakukan, maka $\mathrm{F}_{\text {hitung }}=17,87>\mathrm{F}_{\text {tabel }}=4,05$. Berarti Ho ditolak dan Ha diterima. Artinya terdapat hubungan yang signifikan antara peran orang tua dalam pendampingan dan motivasi belajar dengan hasil belajar, dengan koefisien kolerasi antara variabel $\mathrm{X} 1$ dan $\mathrm{X} 2$ terhadap $\mathrm{Y}$ sebesar 0,687 bertanda positif denga kriteria kuat. Selanjutnya kontribusi variabel X1 dan X2 terhadap Y sebesar 47,20\%. Hal itu berarti peran orang tua dalam pendampingan dan motivasi belajar secara bersama-sama memberi pengaruh sebesar terhadap hasil belajar anak. Sedangkan $52,8 \%$ dipengaruhi oleh faktor lain di luar penelitian seperti; peran sekolah, masyarakat, kecerdasan intelektual, bakat, minat, keterampilan mengajar guru maupun cara belajar peserta didik itu sendiri, dan lain sebagainya.

Hasil belajar merupakan suatu perolehan yang didapat anak setelah mengikuti pembelajaran, yang ditunjukan melalui perubahan dari anak tersebut baik perubahan sikap, pengetahuan, maupun keterampilan. Hasil belajar juga digunakan sebagai tolak ukur anak setelah melakukan pembelajaran. berhasilnya suatu pembelajaran dapat disebabkan oleh beberapa faktor. Susanto (2013: 12), faktor-faktor yang mempengaruhi hasil belajar sebagai berikut: (1) Faktor internal, merupakan faktor yang berasal dari diri peserta didik (kecerdasan, minat, perhatian, motivasi belajar, ketekunan sikap, kebiasaan belajar, serta kondisi fisik dan kesehatan; (2) Faktor eksternal, yaitu faktor yang berasal dari luar diri anak 
yang mempengaruhi hasil belajar yaitu keluarga (orang tua), sekolah dan masyarakat.

Peran serta orang tua dalam pendampingan anak dapat mempengaruhi anak untuk dapat termotivasi dalam belajar, yang akan memicu motivasi anak untuk meningkatkan minat dan belajar. Sebaliknya, jika peran serta orang tua dalam pendampingan anak kurang maka dapat menyebabkan anak kurang termotivasi untuk belajar. Sehingga memberikan dampak terhadap hasil belajar peserta didik yang rendah.

\section{SIMPULAN}

Berdasarkan hasil penelitian dan pembahasan tentang hubungan antara peran orang tua dalam pendampingan dan motivasi belajar dengan hasil belajar anak di era new normal pandemi covid-19 dapat disimpulkan sebagai berikut.

1. Terdapat hubungan yang signifikan antara peran orang tua dalam pendampingan dengan hasil belajar anak di era new normal pandemi covid-19 ditunjukan dengan koefisien kolerasi sebesar 0,605 dengan kontribusi variabel sebesar $36,66 \%$ berada pada taraf "Kuat".

2. Terdapat hubungan yang signifikan antara peran orang tua dalam motivasi belajar dengan hasil belajar anak di era new normal pandemi covid-19 ditunjukan dengan koefesien kolerasi sebesar 0,636 dengan kontribusi variabel sebesar $40,45 \%$ berada pada taraf "Kuat".

3. Terdapat hubungan yang signifikan antara peran orang tua dalam pendampingan dengan peran orang tua dalam motivasi belajar pada anak di 
era new normal pandemi covid-19 ditunjukan dengan koefisien kolerasi sebesar 0,634 dengan kontribusi variabel sebesar 40,20\% berada pada taraf "Kuat".

4. Terdapat hubungan yang signifikan antara peran orang tua dalam pendampingan dan motivasi belajar secara bersama-sama dengan hasil belajar anak di era new normal pandemi covid-19 ditunjukan dengan koefisien kolerasi sebesar 0,687 dengan kontribusi variabel sebesar 47,20\% berada pada taraf "Kuat".

\section{DAFTAR PUSTAKA}

Arikunto, S. 2015. Prosedur Penelitian Suatu Pendekatan Praktik. Rineka Cipta, Jakarta.

Daradjat, Z. 2012. Ilmu Pendidikan Islam. Bumi Aksara, Jakarta.

Djamarah, S. B. 2011. Psikologi Belajar. Rineka Cipta, Jakarta.

Friedman, M. 2014. Buku Ajar Keperawatan Keluarga. EGC, Jakarta.

Hamalik, O. 2011. Psikologi Belajar dan Mengajar. Sinar Baru Algesindo, Bandung.

Harahap, F. I. N. 2018. Pengaruh Hasil Program Parenting Dan Pola Asuh Orang Tua Terhadap Peningkatan Motivasi Belajar Anak Usia Dini. Al-Muaddib. Jurnal Ilmu-ilmu Sosial \& Keislaman. 3(1): 1-14.

Kurniati, E. 2021. Analisis Peran Orang Tua dalam Mendampingi Anak di Masa Pandemi Covid-19. Jurnal Pendidikan Anak Usia Dini. 5(1): 241-256.

Lestari, S. 2012. Psikologi Keluarga. Kencana Preanada Media Group, Jakarta.

Prabhawani, S. W. 2016. Pelibatan Orang Tua Dalam Program Sekolah Di Tk Khalifah Wirobrajan Yogyakarta. (Skripsi). Universitas Negeri Yogyakarta, Yogyakarta.

Prasetyo, F. A. D. 2018. Pendampingan Orang Tua Dalam Proses Belajar Anak. (Skripsi). Universitas Sanata Dharma, Yogyakarta. 
Rakhmawati, I. 2015. Peran Keluarga dalam Pengasuhan Anak. Jurnal Bimbingan Konseling Islam. 6(1): 1-17.

Rusman. 2012. Pembelajaran Tematik Terpadu Teori, Praktik dan Penilaian. Rajawali Pers, Jakarta.

Sanjaya, W. 2012. Strategi Pembelajaran Berorientasi Standar Proses Pendidikan. Kencana, Jakarta.

Santoso, I. 2010. Pola Asuh Orang Tua Dalam Membantu Anak Mengembangkan Disiplin Diri. Rineka Cipta, Jakarta.

Saputri, A. E. 2017. Pendampingan Anak Dalam Keluarga Di TK Pertiwi Kebasen Kabupaten Banyumas. (Skripsi). Universitas Negeri Yogyakarta, Yogyakarta.

Shochib, M. 2010. Pola Asuh Orana Tua Dalam Membantu Anak Mengembangkan Disiplin Diri. Rineka Cipta, Jakarta.

Slameto. 2010. Belajar dan Faktor-Faktor yang Mempengaruhinya. Rineka Cipta, Jakarta.

Soekanto, S. 2012. Sosiologi Suatu Pengantar. Rajawali Pers, Jakarta.

Sudirman. 2016. Interaksi dan Motivasi Belajar Mengajar. Raja Grafindo Persada, Jakarta.

Sudjana. 2013. Teknik Analisis Regresi dan Kolerasi Bagi Para Peneliti. Tarsito, Bandung.

Sugiyono. 2011. Metode Kuantitatif, Kualitatif dan R\&D. Alfabeta, Bandung.

Suprijono, A. 2011. Cooperative Learning Teori \& Aplikasi Paikem. Pustaka Pelajar, Yogyakarta.

Syah, M. 2010. Psikologi Belajar. Rajawali Pers, Jakarta.

Umar, M. 2015. Peran Orang Tua dalam Meningkatkan Prestasi Belajar Anak. Jurnal Edukasi. 1(1): 20-28.

Uno, H. B. 2011. Teori Motivasi dan Pengukurannya. Bumi Aksara, Jakarta.

Wahidmurni, dkk. 2013. Evaluasi Pembelajaran. Nuha Litera, Yogyakarta.

Wahyuni, E. N. 2015. Motivasi dalam Pembelajaran. Universitas Islam Negeri Malang Press, Malang. 
Wardani, A. 2021. Analisis Kendala Orang Tua dalam Mendampingi Anak Belajar di Rumah Pada Masa Pandemi Covid-19. Jurnal Pendidikan Anak Usia Dini. 5(1): 772-782.

Yulianti, T. R. 2014. Peran Orang Tua Dalam Mengembangkan Kreativitas Anak Usia Dini (Studi Kasus Pada Pos PAUD Melati 13 Kelurahan Padasuka Kecamatan Cimahi Tengah). Jurnal EMPOWERMENT. 4(1): 11-24.

Zainal, A. 2012. Penelitian Pendidikan. Remaja Rosdakarya, Bandung. 